\title{
Os Pícaros, os cavaleiros andantes e as \\ BASES PENINSULARES DO ROMANCE PORTUGUÊS
}

\section{Picaros, knight-errants and the peninsular bases of portuguese novel}

\author{
Moizeis Sobreira de Sousa*
}

\begin{abstract}
RESUMO
Frequentemente, os estudos sobre a ascensão do romance português tomam como ponto de partida a influência que modelos narrativos franco-ingleses dos séculos XVIII e XIX exerceram sobre romancistas lusitanos. Essa perspectiva impossibilita perceber que os desenvolvimentos do romance português estão ancorados, acima de tudo, na herança incorporada da tradição romancística peninsular, particularmente aquela que descende de Dom Quixote e da novela picaresca. O objetivo deste artigo, nesse sentido, tem em vista levantar a presença dessas fontes em romances de Camilo Castelo Branco, Almeida Garrett e Alexandre Herculano, figuras que se destacam no período de ascensão do romance português.
\end{abstract}

Palavras-chave: Ascensão do romance português, Dom Quixote, Novela picaresca.

\begin{abstract}
Often, studies on the rise of Portuguese novel take as their starting point the influence that French-English narrative models of the eighteenth and nineteenth centuries had on Lusitanian novelists. This perspective makes it impossible to realize that the Portuguese novel developments are anchored, above all, in the built heritage of novelistic peninsular tradition, particularly

* Universidade de São Paulo.
\end{abstract}


that which descended from Don Quixote and the picaresque novel. The purpose of this article aims to survey the presence of these sources in novels of Camilo Castelo Branco, Almeida Garrett and Alexandre Herculano, novelists who stand out during the rise of the Portuguese novel.

Keywords: The rise of Portuguese novel, Don Quixote, picaresque novel.

\section{INTRODUÇÃo}

A ascensão do romance português tem sido frequentemente estudada como uma intercorrência de modelos narrativos franco-ingleses dos séculos XVIII e XIX ${ }^{1}$. Entretanto, quando esses modelos cruzam os Pirineus, não encontram Portugal em estado lacunar. $O$ romance português já existe e segue o seu próprio caminho. 0 cenário lusitano não deixa pensar na ocorrência de romances antes de haver romancistas, situação que, segundo Roberto Schwarz (2000), descreveria a realidade brasileira até boa parte do século XIX. A pátria de Camões concentra um acervo numeroso de escritores, obras e modelos narrativos enraizados na comunidade lusitana e peninsular, o que impossibilita subscrever a noção de romance enquanto produto de uma transferência cultural. Já no século XVIII, esse gênero dispõe de cidadania portuguesa, dando sequência a uma tradição ficcional calcada em contiguidades nacionais, em processo desde a Idade Média. Pode-se falar, desse modo, em romancistas herdeiros e (re)criadores de modelos diferenciáveis, "com orientações e valores próprios, tônicas e meios característicos" (RAMA, 2001, p. 63).

As narrativas Amadis de Gaula (século XIV), Menina e Moça (1554), de Bernardim Ribeiro, Diana (1559), de Jorge de Montemor, Peregrinação (1614), de Fernão Mendes Pinto , Lazarillo de Tormes (1554), Dom Quixote (1604), de Cervantes, Obras do diabinho da mão furada (século XVIII), de Antônio José da Silva, e A preciosa (1731), de Sóror Maria do Céu, exemplificam núcleos formadores da escrita romancística peninsular. Esses textos partilham uma "história em boa parte comum, numerosos problemas comuns, estabelecendo uma aproximação e instaurando uma comunidade" (RAMA, 2001, p. 70) de modelos extremamente significativos para o romance

1 Sobre esses modelos, vide SOUSA, Moizeis Sobreira de. As fontes setecentistas do romance português. 278 p. Tese (Doutorado) - Faculdade de Filosofia, Letras e Ciências Humanas, Universidade de São Paulo. São Paulo, 2014. 
português. Eles colocam em funcionamento as engrenagens da novela de cavalaria, do romance sentimental e pastoril, do relato de viagens, da novela picaresca e didático-alegórica, matrizes que promovem a ancoragem desse gênero em Portugal.

\section{OS PÍCAROS E OS CAVALEIROS ANDANTES}

Na impossibilidade de abordar detidamente esse conjunto de narrativas, selecionamos Lazarillo de Tormes e Dom Quixote, romances doravante assumidos como matrizes emblemáticas da tradição romancística que se desenvolve nos séculos XVIII e XIX, não apenas em Portugal, mas também em diversas outras partes da Europa. Segundo Bakhtin (2010), o gênero romance se transforma naquilo que ele é, desenvolve as suas possibilidades, amadurece e alcança plenitude nessas obras-chave. Com efeito, elas são responsáveis por organizar um arcabouço narrativo que abre caminho para o contato com as zonas mais familiares e vulgares da realidade, eixos distintivos que esse gênero adquire numa acepção moderna.

A novela picaresca, forma que o Lazarillo de Tormes inaugura, "amadurece uma concepção da personalidade humana que não é retórica" (BAKHTIN, 2010, p. 199), através da qual o homem se liberta dos embaraços das categorias axiológicas convencionais e as pronuncia pelo riso.

Ao redor do pícaro, todas as posições e símbolos elevados em que o homem se reveste de importância e falsidade hipócrita, transformam-se em máscaras. Na atmosfera do embuste, ambiente típico da ficção picaresca, ocorre a transfiguração e o abrandamento desses símbolos e posições, a sua total readequação (BAKHTIN, 2010, p. 198).

Órfão e de condição humilde, Lazarillo de Tormes faz da trapaça o seu mecanismo de mediação com o mundo. A ingenuidade inicial logo cede lugar à esperteza e à falta de escrúpulos, engenhosidade que acumula no contato com a profusão de amos que serve. Esse andamento, convertido em princípio estruturante do romance, conforma o herói de modo cético e antipatético, inabilitando-o para o serviço fiel e uma vinculação perene. Assim, não evita trair (amável e risonhamente) os seus senhores: "[...] passando de amo a amo [...] vai-se movendo, mudando de ambiente, variando a experiência e vendo a sociedade no conjunto [...], de maneira a tornar o livro uma sondagem dos grupos sociais e seus costumes [...], fazendo dele um dos modelos da ficção realista moderna" (CANDIDO, 2004, p. 20-22). Cumpre notar ainda que a diferença entre o estado inicial e final da personagem, 
eixo que norteia a constituição do herói moderno, é herança que a trajetória de Lazarillo também lega. À guisa de ilustração, vejamos brevemente dois exemplos da recuperação picaresca no romance português oitocentista.

N'A Sereia (1865), Camilo Castelo Branco deixa evidente a influência que recebe dessa tradição. Tão logo os protagonistas Joaquina Eduarda e Gaspar Vasconcelos fogem do espaço conventual, tomam o caminho de Sevilha, para onde foram "alegres e descuidados de corregedores e meirinhos, com um passaporte, inventado em Lisboa, no qual [...] se chamavam Carlos e Carolina, naturais de Lisboa, casados, e mercadores" (CASTELO BRANCO, 2005, p. 121). Além de recorrerem ao embuste, o que já os aproxima do pícaro, os amantes escolhem como destino Sevilha, um reduto de anti-heróis por excelência. Lá, "muito sós, muito queridos, muito estranhos às coisas da pátria e aos desgostos dos seus, liam Lazarillo de Tormes" (CASTELO BRANCO, 2005, p. 121), referência que clarifica a identificação picaresca dos heróis camilianos, ainda que não possam ser enquadrados como típicos dessa categoria, já que não pertencem às classes populares. Todavia, permanece o vínculo de parentesco entre os textos.

A brasileira de Prazins (1882) é outro caso emblemático do aproveitamento dessa linhagem narrativa. O personagem Veríssimo é quem encarna mais de perto os expedientes desse veio. Depois de tentar a carreira de humanidades em Coimbra e ter assentado praça nas fileiras miguelistas, ele passa a viver como um típico vadio, mantendo-se, à custa de uma tia, "regaladamente de papo acima, tocando flauta e a trasfegar em si o resto da garrafeira" (CASTELO BRANCO, 1995, p. 99). Instado a seguir a vida religiosa, vai para o seminário em Braga, não por vocação, mas para não contrariar sua mantenedora.

Ao invés de se dedicar aos compêndios teológicos, Veríssimo consome a mesada que recebe da irmã de seu pai em farras com Torquato Nunes, parceiro de vadiagens. Após a morte da tia, de quem herda a casa e algumas vinhas, vive mais algum tempo largamente, mas logo o patrimônio é totalmente delapidado, forçando-o a perambular por diversas ocupações. Foi amanuense em Alijó, escudeiro do capitão-mor de Murça, feitor de um fidalgo do Douro, mestre das primeiras letras no Porto até galgar o posto de sósia de D. Miguel em Braga. Aproveitando-se das semelhanças que tinha com o monarca absolutista, Veríssimo segue os conselhos de Torquato e decide se passar por D. Miguel, operando a transfiguração e o abrandamento de símbolos e posições que remetem à atuação dos ancestrais pícaros. Esse jogo resulta numa corte de miguelistas, ávida por servir e defendê-lo. No exercício farsesco do real cargo, ele concede benesses, arregimenta partidários, então movidos pela esperança de recolocar D. Miguel no trono, e explora financeiramente os seus súditos. 
Desfeita a fraude, Veríssimo é preso, mas logo é posto em liberdade pelo conselheiro Leite, antigo amigo do seu pai. Sem maiores dissabores, segue novamente a vida de vadio até se envolver na guerra da Patuleia. Inicialmente, atua como setembrista, mas, considerando a possiblidade de obter mais vantagens no lado oposto, não hesita em recorrer novamente ao expediente pícaro da rotatividade. Dessa maneira, deserta e passa a dar vivas à Carta Constitucional, atitude que lhe rendeu, como calculado, um cargo público na aduana.

O histórico de trapaças e a série de perambulações não deixam dúvidas acerca do ancestral picaresco de Veríssimo. Através dele, cumpre destacar, Camilo Castelo Branco revolve a cena social portuguesa das décadas de 1820 e 1840, acrescentando-lhe uma intepretação despida da seriedade historiográfica e pronunciando os frequentes cataclismos políticos dessa época pelo ângulo cínico desse vadio simpático. A inserção da picaresca, cabe sublinhar, não é prerrogativa do romance camiliano. Em textos coetâneos, como Os Maias (1888) ou A Relíquia (1887), de Eça de Queirós, ela também é perceptível. Todavia, na impossibilidade de analisar essas outras manifestações aqui, deixaremos essa questão apenas indicada.

Feita essa sucinta análise da recuperação de Lazarillo de Tormes, tratemos agora, também em linhas gerais, da importância de Dom Quixote. Esse romance desenha uma narrativa em que a artificialidade da linguagem heroico-cavalheiresca é fraudada pelo jogo combinatório e dialógico que entrelaça o senso imediatista de Sancho Pança à loucura do Fidalgo de la Mancha, que assentava "ser verdade toda aquela máquina de sonhadas invenções que lia” (CERVANTES, 1978, p. 30) em Palmeirim de Inglaterra (1541-1543), Amadis de Gaula e congêneres. À luz da ressonância paródica que a presença desses textos instaura, organizada não apenas pelo contraste entre Dom Quixote e seu escudeiro, mas por meio do manejo ambíguo da cosmovisão que eles carregam, um amplo quadro da realidade humana é desvendado.

Como a trapaça do pícaro, a tolice e/ou desajuste dos protagonistas de Cervantes esclarece uma multiplicidade de experiências que a linguagem dos gêneros elevados tende a escamotear. É precisamente a despropositada vontade de Dom Quixote de "ir por todas as quatro partes do mundo buscar aventuras, [...] como incumbe à cavalaria e aos cavaleiros andantes" (CERVANTES, 1978 , p. 36), que possibilita, consoante um variegado painel de aventuras, o conhecimento das engrenagens que fazem girar o mundo e as pessoas. Assim, "a ligeireza dos pés e a subtileza das mãos" (CERVANTES, 1978, p. 36) do vendeiro que sagra Dom Quixote cavaleiro é trazida à luz a partir da aspiração tresloucada do fidalgo. Da mesma forma, a compleição rude e grosseira da Dulcineia é iluminada pela retórica cortesã que o protagonista emprega. 
Levando em consideração o patrulhamento enfrentado pelas produções romancísticas a partir do século XVI, não parece descabido inferir que os desvarios de Dom Quixote e a simploriedade de Sancho Pança resultem de um malabarismo discursivo aplicado por Cervantes para blindar sua obra e contornar a ação da censura. Ao construir um personagem que perde a razão porque lê, o romancista ibérico caminha, a priori, na direção sinalizada pela repressão intelectual ${ }^{2}$, interessada em desestimular a leitura e admoestar acerca dos malefícios subjacentes à tentativa de implantar as matrizes literárias na realidade corrente. Vale lembrar que, sobre o romance, recaia a acusação de provocar "devastações psicológicas nos leitores e, no grau máximo, fazer enlouquecer" (SITI, 2009, p. 169). Sob esse prisma, o ridículo que envolve Dom Quixote pode ser tributado ao efeito didático insinuado pela obra, alinhado, por conseguinte, às diretrizes estéticas validadas pelo aparato censório. Essa hipótese fica fortalecida, por exemplo, no episódio em que o cônego de Toledo enceta um colóquio sobre o romance com o cura da aldeia em que Dom Quixote vive. Veja-se mais de perto a cena:

- Eu por mim, senhor cura, acho [...] que são prejudiciais [...] livros a que chamam de cavalaria, [...] que só tratam de deleitar e não de instruir, ao contrário do que sucede com as fábulas apologias [...]. O deleite [...] deve resultar da formosura e harmonia [...] e tudo quanto é feio ou desconcertado não nos pode causar satisfação alguma. [...] Que espírito, [...] poderá ficar deliciado ao ler que uma grande torre cheia de cavaleiros vai por esses mares adiante, como navio com vento de feição, e anoitece na Lombardia, e amanhece nas terras do Preste João das Índias [...]? E, se a isto se me responder que os autores desses livros os escrevem como obras de imaginação, [...] direi que a mentira é tanto mais saborosa quanto mais verdadeira se afigura, e agrada tanto mais quanto se aproximam do possível [...]. Hão de se casar as fábulas mentidas com o entendimento dos que as lerem, [...] de modo que andem juntas a admiração e a alegria, e estas coisas todas não as poderá fazer quem fugir da verossimilhança e da imitação, em que consiste a perfeição do que se escreve. Nunca vi um livro de cavalarias com unidade de ação [...]. Além disso, são [...] lascivos nos amores, [...] por isso, dignos de serem desterrados da república cristã como coisa inútil. O cura [...] redarguiu-lhe que [...] queimara todos os de D. Quixote [...], com o que muito se riu o cônego, e alegou que, apesar de ter dito mal desses livros, achava neles uma coisa boa, que era darem assunto para se poder manifestar um vivo engenho, porque tinham vasto e espaçoso campo, [...] narrando, ora

2 Sobre a relação entre romance e censura, vide SOUSA, Moizeis Sobreira de. AS fontes setecentistas do romance português. 278 p. Tese (Doutorado) - Faculdade de Filosofia, Letras e Ciências Humanas, Universidade de São Paulo. São Paulo, 2014. 
um sucesso trágico [...], ora um acontecimento alegre. [...] a solta contextura destes livros dá lugar a que o autor possa mostrar-se épico, lírico, trágico, cômico [...] (CERVANTES, 1978, p. 281-284).

Essa longa intervenção dos religiosos mapeia a crítica ao romance e os preceitos estéticos advogados pelo sistema cultural hegemônico, remindo a obra em análise à condição de ágora, onde o discurso literário se desdobra em afirmar a representação do mundo e os mecanismos que envolvem esse ato. A concepção de literatura pleiteada pelo cônego advém do consórcio estabelecido entre poética clássica e o sistema de representação eleito pela ordem católico-absolutista. Assentado na hierarquização do ato mimético, esse sistema defende a combinação do deleite à instrução, seguindo os postulados da Ars Poetica de Horácio. Como critério de equacionamento estético, ela adota os princípios aristotélicos da verossimilhança, do decoro e das três unidades (ação, espaço e tempo). A anexação dessas regras corporifica um ideal artístico em que a ênfase recai no espetáculo moral do enaltecimento da cultura devota e no seu modelo harmonioso de experiência humana, em detrimento de uma roupagem mimética policromática. Amparando-se nesses pressupostos, a mentalidade do Antigo Regime (aqui representada pelo cônego e o cura) se apropria, consoante seus interesses, do código composicional clássico e sustenta que a Natureza é essencialmente imutável e universal, cabendo à arte, desse modo, perseguir como objetivo a adequação a um modelo, conforme a prescrição dos gêneros elevados. Nesses termos, o romance se apresenta, não raro, como forma dissonante, inadequada, ética e esteticamente, às prescrições poéticas canônicas. Por isso, a contextura camaleônica e o modo proteico, que se nutre da mistura de traços épicos, líricos, dramáticos e trágicos, características que o religioso de Toledo visualiza na escrita romancística, são atribuídas a um fazer literário desprestigiado e potencialmente nocivo, decorrente da insubordinação às regras clássicas de composição e ao status quo.

A dicção dialógica e o tom irônico que prevalece na totalidade do romance não permitem, no entanto, associá-la de forma pacífica ao discurso que faz apologia aos pressupostos clássicos-censórios. Em sua leitura de Dom Quixote, Milan Kundera observa que "compreender o equacionamento textual de Cervantes é ter de enfrentá-lo como ambiguidade, em que, em vez de uma só verdade absoluta, muitas verdades relativas se contradizem, restando como única certeza a sabedoria da incerteza" (KUNDERA, 2009, p. 14). O riso que Dom Quixote suscita é extremamente ambíguo. Simultaneamente, ele problematiza a leitura de romances e fustiga o status quo sustentado pela matriz cultural predominante no Antigo Regime. Note-se que o padre-mestre, figura que assoma com voz de autoridade, é amiúde inquerido pelo barbeiro acerca das razões pelas quais determina a queima dos livros 
na fogueira. Além disso, sua constituição guarda vestígios de embusteiro e doses de parcialidade, o que finda por gerar um efeito sub-repticiamente cômico, ainda que a cena faça apelos à gravidade.

A loucura de Dom Quixote, além de servir de salvo-conduto, é sintomática de uma inadequação ao mundo, aspecto que introduz a dimensão trágica da obra. Embora suscite o riso, o seu alheamento em face do mundo exterior não deriva de um embuste, antes tem origem na inabalável certeza de que o ordenamento cósmico não corresponde às contingências internas devido a um encantamento operado por maus demônios. A disjunção entre o ideal concebido na interioridade e a ação/imagem que se desenrola na realidade é interpretada como uma atitude inoportuna do prosaísmo da vida. Desse modo, quando Dom Quixote sai a campo, o triunfo dos adversários é sempre atribuído à manobra de um encantador ou à imanência mal conformada dos indivíduos, inaptos a compartilhar o sistema de valores que o conduz. Ao ser engaiolado, o engenhoso fidalgo não admite a possibilidade de ter falhado. Ao contrário, a desventura surge como resultado da ação de um demônio. O confronto com a aparência vulgar de Dulcineia, descoberta de forma diametralmente oposta à imagem da dama sublime, é diluído pela certeza de que a mulher amada foi vítima de um encantamento. Em que pese o não acolhimento das ações do herói pela realidade, sua alma "repousa, fechada e perfeita em si mesma, como uma obra de arte ou uma divindade" (LUKÁCS, 2000, p. 102-103).

O descompasso entre a aventura ontológica e o mundo redunda em ausência de sentido, ou melhor, numa dilacerante busca pela essência, corporificada sempre como intenção, como um fundamento enigmático e inapreensível a ser, debalde e relutantemente, desvendado. Nas sociedades onde Deus cumpre a função de unidade constitutiva da existência, esse hiato se converte no exílio da divindade. Nesse sentido, Dom Quixote "situa-se no início da época em que o deus do cristianismo começa a deixar o mundo; em que o homem torna-se solitário e é capaz de encontrar o sentido e a substância apenas em sua alma, nunca aclimatada em pátria alguma; em que o mundo [...] é abandonado a sua falta de sentido imanente [...]" (LUKÁCS, 2000, p. 106). A exigência de vincular as individualidades a uma totalidade orgânica, fechada e homogênea, fundada numa teodiceia que doa sentido e oferece asilo transcendental, marca dos gêneros elevados, colide com o desenho problemático e demoníaco do homem que a escrita romancística compreende. "Um dos principais temas [...] do romance é justamente [...] a inadequação de um personagem ao seu destino e à sua situação. O homem ou é superior ao seu destino ou inferior à sua humanidade" (BAKHTIN, 2010, p. 425), de maneira que a veiculação de um suporte de valores suprapessoal não encontra ressonância dogmática na trajetória desse herói emergente. 


\section{Consequentemente,}

Dom Quixote sai de sua casa e não tem mais condições de reconhecer o mundo. Este, na ausência do Juiz Supremo, surge como uma temível ambiguidade; a verdade divina se decompõe em centenas de verdades relativas. Assim, o mundo dos tempos modernos irrompe e, com ele, sua imagem e modelo de romance (KUNDERA, 2009, p. 13-14).

Os desdobramentos ulteriores da escrita romancística estão, com efeito, arraigados nessa consciência literária que Dom Quixote sintetiza mediante a reorientação dos modelos ficcionais disponíveis nas tradições ibérica e ocidental. Ao lado de Lazarillo de Tormes, o texto cervantino proclama as duas exigências constitutivas desse gênero no período de sua ascensão ao centro do sistema literário, quais sejam: "o romance deve ser o reflexo multilateral de uma época e apresentar a crítica do discurso literário, sobretudo a problematização da matriz romancística” (BAKHTIN, 2010, p. 201-202). As categorias de tolo, embusteiro e inadequado ao mundo, legadas por esses textos, são "reacentuadas e reinterpretadas de modos diferentes na história posterior do romance, prologando a discussão que eles deixaram a concluir" (BAKHTIN, 2010, p. 200).

Um levantamento detalhado atestará os genes de Dom Quixote na constituição de Ema Bovary e seu trágico enfado ante o estreitamento da realidade corrente; na sede de infinito de Julien Sorel (O Vermelho e o Negro, de Stendhal); na errância idealista de Lucien de Rubempré (As Ilusões Perdidas, de Balzac); nas aventuras, aparentemente desconectadas da realidade, de Gulliver (As viagens de Gulliver, de Swift); nas andanças iluministas de Cândido (Cândido ou o Otimismo, de Voltaire) e Jacques (Jacques le fataliste, de Diderot). Contudo, o que parece mais interessante pontuar é a ascendência quixotesca dos heróis plasmados pelo romance português. Em que pese o reconhecimento da influência cervantina sobre a escrita romancística lusitana, quando se busca localizar a gênese de seus heróis, a geografia que se descortina está, grosso modo, limitada ao além Pirineus, isto é, no individualismo econômico e filosófico de Robinson Crusoé e/ou no senso de realidade decalcado por Balzac, Stendhal e Flaubert.

A herança de Cervantes, se considerada devidamente, abre caminho para o tratamento dos problemas específicos e das particularidades que a forma do romance manifesta em Portugal, malgrado a relação que mantém com os desdobramentos desse gênero em outros espaços culturais. A adoção dessa perspectiva demonstrará que o eixo estrutural de um conjunto fundamental de romances portugueses e heróis remonta, direta ou indiretamente, às aventuras do engenhoso fidalgo. Veja-se na sequência alguns exemplos desse diálogo. 
O percurso cultural, político e social que o narrador de Almeida Garrett faz em Viagens na Minha Terra (1846) é acompanhado de perto por Dom Quixote. As tensões dialéticas e os diversos pares antinômicos (frade/ barão, liberal/absolutista, Frei Dinis/Carlos, literatura/sociedade) em torno dos quais elas se organizam, dando forma ao romance, aproveitam explicitamente o espólio do Cavaleiro da Triste Figura. 0 entrechoque das visões de Sancho Pança e Dom Quixote se imiscui ao andamento do texto e à trajetória dos personagens. "Nesta viagem Tejo arriba, ou melhor, nesta obra, em que está simbolizada a marcha do progresso social português" (GARRETT, 1973, p. 32), o cavaleiro andante e o seu escudeiro descortinam o intricado símbolo do espiritualismo-materialismo, base da operação hermenêutica do narrador-viajante:

Houve aqui há anos um profundo e cavo filósofo de além Reno, que escreveu uma obra sobre [...] o Progresso. Descobriu ele que há dois princípios no mundo: o espiritualista, que marcha sem atender à parte material e terrena desta vida, [...] e que pode bem [...] simbolizar-se pelo famoso mito do cavaleiro da mancha, D. Quixote; o materialista, que, sem fazer caso nem cabedal dessas teorias, em que não crê, e cujas impossíveis aplicações declara todas utopias, pode bem representar-se pela rotunda e anafada presença do nosso amigo velho, Sancho Pança. Mas, como na história do malicioso Cervantes, estes dois princípios tão avessos [...] andam contudo juntos sempre, ora um mais atrás, ora outro mais adiante, empecendo-se muitas vezes, coadjuvando-se poucas, mas progredindo sempre. E aqui está o que é possível ao progresso humano. E eis aqui a crônica do passado, a história do presente, o programa do futuro. Hoje o mundo é uma vasta Barataria, em que domina el-rei Sancho. Depois há de vir D. Quixote. (GARRETT, 1973, 31-32).

Esse fragmento, disposto logo no capítulo II, contém a primeira referência a Dom Quixote. Ele tem função basilar, pois expõe o argumento central da narrativa e funciona como núcleo aglutinador das demais entradas quixotescas inseridas ao longo das Viagens. A representação da sociedade portuguesa do presente (década de 1840), então dominada pela lógica dos barões e pela corrupção dos valores liberais, é condensada na imagem da vasta Barataria em que domina el-rei Sancho, cuja antítese se traduz na vaga esperança regeneradora encabeçada por Dom Quixote, signatário de um futuro incerto. Como princípios contraditórios de um movimento dialético, essas figuras e o tempo que elas representam não se apresentam de forma fixa. Passado e porvir coexistem numa dinâmica instável, atravessada por uma temporalidade conflituosa e descolada da duração cronológica. Os relógios de Sancho Pança e Dom Quixote encenam um jogo temporal equili- 
brado na alternância, na interpenetração. O personagem Carlos, por exemplo, que inicialmente atua como soldado liberal, identificando-se ao cavaleiro andante, finda no papel de Sancho, isto é, barão, "o mais desgracioso e estúpido animal da criação" (GARRETT, 1973, p. 84). A mesma ambivalência acompanha a pintura do frade, que "era, até certo ponto, o dom Quixote da sociedade velha" (GARRETT, 1973, p. 84), no entanto, reconvertido, com outras tintas, no mundo atual. Dessa maneira, Garrett preserva a tessitura ambígua e multidimensional em que Cervantes cosera seus entes ficcionais ${ }^{3}$, "integrando-se plenamente à interpretação do livro espanhol e servindo-se dele para expressar o desencanto ideológico, social e político em que se se encontrava a geração que, vinte anos antes, tinha lutado por construir uma sociedade nova, sob o sonho romântico-liberal" (ABREU, 1994, p. 191), ora tão distante da realidade factível.

A gestão do legado cervantino também encontra espaço na caudalosa e multiforme escrita romancística de Camilo Castelo Branco, a tal ponto que Ramalho Ortigão afirma, no prefácio que escreveu para a edição do Amor de Perdição de 1889, que não é aos franceses que se deve comparar Camilo para estabelecer sua genealogia estética, mas aos espanhóis do século XVII.

O romanesco de Camilo [...] procede incialmente da dinastia dos "Amadisis" e dos "Palmeirins", e participa do gênio peninsular de toda a literatura poética subsequente: do lirismo contemplativo de Santa Tereza, do misticismo dramático de Calderón e de Lope de Vega, da sátira picaresca de Cervantes [...] e de Quevedo" (ORTIGÃO, 1892 apud ABREU, 1994, p. 261).

Embora careça ser matizada, essa declaração não deixa esquecer que o intercâmbio que a produção camiliana celebra com outras literaturas não se concentra apenas na rota Lisboa/Paris-Londres. No Curso de Literatura Portuguesa (1876), Camilo declara, baseado num ponto de vista que dialoga com Ramalho Ortigão, que a literatura portuguesa está em atraso devido ao fato de Portugal ter sido muito tardio "a desertar da escola francesa” (CASTELO BRANCO, 1993, p. 1445). Como Maria Fernanda de Abreu, podemos dizer que

do que lemos e analisamos na obra do nosso grande romancista, fica-nos já a certeza de que Cervantes foi um desses escritores que lhe sugeriram maneiras de encarar o real e os processos de

3 Desse fragmento, é interessante reter ainda que o romancista português formula sua concepção dialética de homem e história a partir de um Dom Quixote entrelaçado à recepção setecentista de Hegel, o profundo e cavo filósofo de além Reno a quem o narrador se refere incialmente. Em certa medida, a pioneira teoria que o autor da Estética concebe sobre o romance tem por eixo a contradição espiritualismo/materialismo, em alguma medida influenciada por Dom Quixote. 
fazer romances e que sua presença se estende praticamente desde o princípio até o fim da sua carreira literária, assumindo as mais variadas formas e intenções (ABREU, 1994, p. 266-267).

Onde Está a Felicidade? (1856) apresenta um exemplo paradigmático de uma das facetas cervantinas mais encenadas pela ficção camiliana: o herói ou heroína vítima de romances. Equivocadamente, esses personagens são "registrados pela crítica portuguesa apenas como ocorrência de bovarismo" (ABREU, 1994, p. 329), sem considerar Dom Quixote como um ancestral, ao mesmo tempo, de Madame Bovary e Onde Está a Felicidade?.

Guilherme do Amaral, o protagonista deste último, se notabiliza como leitor de romances, donde advém sua ânsia por instaurar, na vida social, um conjunto de práticas extraídas do acervo de leituras que faz. Desse modo, reassenta, sob a capa do homem fatal, tomado emprestado do imaginário romântico, o tópico do indivíduo inadequado ao mundo, cuja mundividência é posta em causa pela consciência multivocal e problematizadora do narrador. o modo como Guilherme é anunciado, conforme o trecho seguinte, atesta o quanto seu caráter se irmana ao de Dom Quixote:

Os romances fazem mal a muita gente. Pessoas propensas a adaptarem-se aos moldes que admiram e invejam na novela, perdem-se na contrafacção, ou dão-se em pábulo ao ridículo. [...]. Homens sem originalidade, ou originalmente tolos, macaqueiam tudo que sai fora da esfera comum. Crédulos até ao absurdo, aceitam como reais e legítimos os partos excêntricos de cabeças excêntricas, e prometem-se dar tom a uma sociedade mesquinha, onde não [aparece] o [...] homem fatal. [...] E, depois, das duas uma: ou atingem o apogeu da perversidade, calcando a honra, cuspindo na face da sociedade $[\ldots]$ ou $[. .$.$] imaginam-se homens excepcionais [...] Quero$ mostrar-vos o Sr. Guilherme do Amaral. Ides conhecer uma vítima dos romances. [...] A sua paixão predominante não era a caça, nem a pesca, nem cavalos: era o romance. Comprou centenas de volumes franceses, leu de dia e de noite, decorou páginas, que lhe eletrizaram o coração combustível [...]. / Impregnado desta lição [...], olhou em torno se si, e viu-se só. Queria mundo, queria ar, ansiava nutrição para a fome de impressões fulminantes (CASTELO BRANCO, 1981, p. 37-38).

Ainda que haja algumas diferenças no que concerne à bibliografia consultada pelos heróis - Dom Quixote lia romances de cavalaria, ao passo que Guilherme do Amaral era leitor de romances franceses - e ao modo como são encaminhadas as tensões advindas do choque entre mundo lido e mundo vivido - Cervantes sustenta o seu texto a partir do equilíbrio entre o cômico e o trágico, já Camilo se encaminha na direção do riso desapiedado-, sobre os dois incide o mesmo pathos ontológico: a busca por descortinar um 
referencial literário na vida social, intenção que é refratada, no caso camiliano, pela visão pragmática do narrador, descendente de uma mundividência que pode ser associada a Sancho Pança. Dito isso, é escusado apontar que o embate dessas perspectivas se converte em princípio estruturante, como nas Viagens, de Almeida Garrett.

Em Coração, Cabeça e Estômago (1862) e em A Mulher Fatal (1870), Camilo explora outra camada imprescindível do romance de Cervantes, isto é, a procura pela Dulcineia Encantada, aspecto reinventado nas trajetórias de Silvestre da Silva e Carlos Pereira, tipos emblemáticos do cavaleiro-enamorado oitocentista. Tal como o engenhoso fidalgo, a mediação entre esses personagens e as mulheres que amam é feita por uma visão que transmuta a realidade empírica em ideal, fazendo-os enxergá-la de acordo com a imagem cristalizada pelo desejo.

o princípio que norteia a relação de Carlos (A mulher Fatal) com a matéria amorosa pode ser resumido neste paradigma: “[...] o amor é capaz de corrigir as imperfeições da criação [...]; faz junho outubro" (CASTELO BRANCO, 1968, p. 34). A crença que o compele a procurar a mulher fatal não se deteriora com o tempo, mesmo que a moldura em que enquadra as filhas de Eva se estilhace sucessivas vezes. $O$ romance tem seu andamento organizado em torno da alternância cíclica entre as histórias de amor que o herói projeta (cinco, no total) e os respectivos golpes de realidade que cada uma acarreta. No entanto, as experiências são debalde vividas, de maneira que somente o seu status social se modifica no decurso da narrativa, permanecendo o arcabouço interno intacto, como ocorre com Dom Quixote. Na quinta aventura amorosa, Carlos ainda conserva as "ingenuidades tímidas do primeiro amor" (CASTELO BRANCO, 1987, p. 1159). A despeito das manchas que maculam a imagem social de Cassilda Arcourt, seu último amor, ele não retrocede à esperança de regenerá-la através desse sentimento, seguindo os modelos de conduta que recolhera na literatura, notadamente no Manon Lescaut (amor fulminante) e n'A Dama das Camélias (mito da cortesã pura).

o percurso de Silvestre da Silva (Coração, Cabeça e Estômago) é, até certo ponto, muito parecido com o do herói de $A$ Mulher Fatal. Os seus esforços para encontrar a dama encantada resultam em sete aventuras, todas malogradas. Tal como ocorre com Carlos, o que aciona o desejo amoroso de Silvestre é o sentido da visão. A partir de uma imagética distanciada da realidade factual, ele encaminha uma busca cavalheiresca pela mulher amada. À diferença de Carlos, no entanto, o amor não converte o destino de Silvestre da Silva em fatalidade. Findada a fase do coração, "aqueles dez anos em que nós vimos Silvestre fazer tolice brava" (CASTELO BRANCO, 2003, p. 8), ele se vale da experiência acumulada nesses tempos para se metamorfosear, incorporando o imediatismo e a trapaça à sua personalidade, traços que o 
guia à etapa do estômago - última de sua vida -, definida como a "sepultura das quimeras que o entonteceram na mocidade e consequência da direção que ele deu aos projetos, raciocínios e sistemas da cabeça ${ }^{4}$ " (CASTELO BRANCO, 2003, p. 8). Em conjunto, a soma dialética desses períodos, díspares mas complementares, conforma uma narrativa em que o jogo das perspectivas de Dom Quixote e Sancho Pança se mantém como fio condutor. Na fase inicial, Silvestre segue a bússola do cavaleiro andante. Já no final, é realçada a imago mundi do fiel escudeiro. Por se tratar de um texto narrado, em sua maioria, em primeira pessoa, não há, como nos outros casos, a disputa dialógica entre o herói e o narrador, de maneira que a oscilação entre os vértices cervantinos fica plasmada na consciência e trajetória do protagonista.

Ainda no âmbito da ficção camiliana, vejamos mais um exemplo da presença de Dom Quixote. N'A Queda dum Anjo (1866), consta um dos acervos de referência a Cervantes mais explícitos e ricos que Camilo amealhou. A comunicação que se estabelece entre o protagonista, Calisto Elói, e Dom Quixote/Sancho Pança grassa ao longo da narrativa. Partidário dos códigos feudais da aristocracia, Calisto era versado em latim, língua que falava como se fosse o idioma materno, e leitor contumaz de "cronicões, histórias eclesiásticas, biografias de varões preclaros, corografias, legislação antiga, forais, memórias da Academia Real da História portuguesa, catálogo de reis, numismática, genealogias, anais, poemas de cunho velho [...]." (CASTELO BRANCO, 2001, p. 8), gêneros que serviam de modelo para a "bizarra índole de antigo cavaleiro" (CASTELO BRANCO, 2001, p. 73) que o move a abrigar "no peito a generosidade com que os heróis dos Lobeiras, Cervantes, Barros e Morais se lançavam às aventurosas lides, no intento de corrigir vícios e endireitar as tortuosidades da humana maldade" (CASTELO BRANCO, 2001, p. 73), livrando a "monarquia portuguesa de ser reduzida, no mapa-múndi, à realidade da ilha Barataria do Miguel de Cervantes" (CASTELO BRANCO, 2001, p. 27).

Esse perfil, inegavelmente quixotesco, também desencadeia uma resposta paródica do narrador, que, munido de ironia e comicidade, promove a relativização do pensamento heroicizante e monológico do personagem, bem como das matrizes literárias que o fundamentam. O mundo burguês-capitalista do Portugal oitocentista, cujo painel o olhar satírico do narrador costura a partir do contraste com a cosmogonia do protagonista, se configura como espaço estrangeiro às pretensões incomunicáveis de Calisto Elói, o que o obriga a se realinhar ontologicamente e ingressar no espírito do século, o que redunda no despojamento da indumentária e da mentalidade 
cavalheiresca. Assim, "caiu o anjo, e ficou simplesmente o homem, homem como quase todos os outros, e com mais algumas vantagens [...]. Dinheiro a rodo! [...] Saúde de ferro! E barão" (CASTELO BRANCO, 2001, p. 217). Nesse desfecho, para além das semelhanças que há entre Calisto Elói e o conjunto Dom Quixote/Sancho Pança, está aquilo que mais aproxima Camilo Castelo Branco de Cervantes: a constituição do romance como forma que repõe ao indivíduo sua complexidade humana, de modo a se esquivar da obra literária enquanto prescrição de utilidade, já que, para ambos, o "conhecimento é a única moral do romance" (KUNDERA, 2009, p. 13). O recurso à sátira e aos espelhos ambíguos que ela propicia, técnica que Camilo apreende com Cervantes, permite talhar um contingente de heróis, dentre os quais se inclui Calisto Elói, cujas trajetórias não se encerram com protestos de apreço à sã moralidade, antes apontam para uma consciência literária polêmica e elástica, na qual a verdade se dispersa numa multiplicidade de vozes e instâncias, numa movimentação simultaneamente apologética e polêmica.

Se a relação Camilo/Cervantes fosse aprofundada, o que não cabe nesse espaço, seria possível encontrar ainda o timbre cervantino em diversos mecanismos que a pena camiliana desenvolve, tais como a tópica do manuscrito encontrado - verificada em Amor de Perdição, A Caveira da Mártir e $A$ Sereia -, a loucura-sublime, presente, por exemplo, em $A$ doida do Candal e A Bruxa do Monte Córdova.

Cumpre ainda, para encerrar esse breve panorama do comparecimento de Dom Quixote na constituição estrutural do romance português, fazer menção a Alexandre Herculano.

Em 1851, por ocasião do lançamento das Lendas e Narrativas, Herculano Herculano afirma que esse livro representa "as primeiras tentativas do romance histórico que se fizeram na língua portuguesa. Monumentos dos esforços do autor para introduzir na literatura nacional um gênero amplamente cultivado nestes [...] tempos em todos os países da Europa" (HERCULANO, 1980, p. 1). De fato, essa empreitada se tornará um dos pontos altos e traços distintivos da escrita romancística portuguesa do século XIX. Ela é, não raro, associada ao legado de Walter Scott, em quem Herculano teria se filiado para engendrar a sua modalidade histórica, confirmando o vaticínio que Maria Fernanda de Abreu lança sobre a crítica peninsular, a qual, "[...] desde sempre, reconhece repetidamente as dívidas das literaturas espanhola e portuguesa [...] para com a obra de Walter Scott” (ABREU, 1994, p. 117). Tal juízo, no entanto, deixa de lado que, se "o romance histórico scottiano é a continuação direta do grande romance social realista do século XVIII" (LUKÁCS, 2011, p. 47), muito disso se deve à recuperação da literatura cavalheiresca medieval que o autor escocês efetua mediante a leitura de Dom 
Quixote ${ }^{5}$. Segundo Rebelo da Silva, um dos poucos a identificar essa ligação, foi com Cervantes que Scott aprendeu a compor a "individualidades dos caracteres; revelando-lhe o segredo de pintar as cenas com tanta verdade de costumes" (SILVA, 1909, p. 36). A cadeia que liga Herculano a Walter Scott, desse modo, é extensiva a Cervantes. $O$ autor de Eurico não teria manuseado o amplo cabedal de materiais cavalheirescos que acumulou sem o recurso ao Dom Quixote. A sua crença de que a Idade Média foi o apogeu da história de Portugal, já que nessa época estaria a formação e as raízes da nacionalidade, o levou a trabalhar arduamente na construção de um acervo histórico que recompusesse a narrativa desse período, instrumental que serviu de esteio para os textos literários que compôs, particularmente as obras de caráter histórico, maioria absoluta no conjunto de sua produção romancística.

Nos dois primeiros artigos que escreveu para a série Novelas de Cavalaria Portuguesa, posteriormente reunidos no volume IX dos Opúsculos, ele segue o desejo de conhecer "as ideias de honra, de valentia e de amor, que ocupavam quase exclusivamente os espíritos durante a Idade Média e que se reproduziram em todas as formas sociais e instituições daquela brilhante época" (HERCULANO, 1908, apud ABREU, 1994, p. 129). O acesso ao elemento cavalheiresco, como se pode perceber, não se dá apenas pela via historiográfica tradicional, antes a fonte literária também é valorizada como caminho para obtê-lo. Na relação literatura-sociedade, tal como concebe Herculano, o trabalho de criação está estreitamente articulado aos costumes do período em que se situa, visto que "a literatura de todas as épocas [...] não é mais do que um eco harmonioso, ou um reflexo resplendente das ideias capitais, que vogam em qualquer delas" (HERCULANO, 1908, p. 88). Assim, o resgate do tempo medieval passa pelas novelas de cavalarias, que, por sua vez, chegam ao século XIX graças à leitura do engenhoso fidalgo. É sintomático dessa ramificação o tratamento dispensado por Herculano ao Amadis de Gaula, cuja análise entrelaça à autoridade incontestável do Dom Quixote em matéria cavalheiresca, conforme reconhece nos opúsculos.

\section{Considerações Finais}

Portanto, é inserindo-se no contexto da tradição ibérica que as idiossincrasias do romance português podem ser compreendidas em escalas mais abrangentes, tal como atesta a narrativa histórica elaborada por Herculano, cujas linhas temáticas e estruturas básicas recuam à tradição ficcional medieva peninsular. Essa abordagem propiciará, indo mais adiante,

5 Sobre a recuperação da literatura cavalheiresca por Scott, conferir Maria Fernanda 
a percepção de que parte significativa do substrato narrativo que Cervantes reatualiza em Dom Quixote está nas novelas de cavalaria-Amadis de Gaula, Palmeirim de Inglaterra - e pastoril -Diana -, paradigmas de que portugueses e espanhóis foram precursores, tendo exercido influência substancial nas literaturas germânica, inglesa e francesa. Walter Scott, já no século XIX, parecia partilhar dessa ideia. Em sua opinião,

The fame of Amadis of Gaul has reached to the present day, and has indeed became almost provincial in most languages of Europe. But this distinction has been attained rather in a mortifying manner: for the hero seems much less indebted for his present renown ho his historians, Lobeira, Montalvo, and Herberay, than to Cervantes, who selected their labors, as one of the best known books of chivalry, and therefore the most prominent object for his ridicule. [...] the renown of the victor has carried down to posterity the memory of the vanquished; [...] we believe no reader is acquainted with Amadis of Gaul, otherwise than as the prototype of Don Quixote de la Mancha. (SCOTT, 1803, apud ABREU, 1994, p. 124).

O romance de cavalaria, defende Sampaio Bruno, está na origem do romance português moderno. "Na sua ridicularização, consagrada no Dom Quixote, observa-se o prenúncio do futuro" (BRUNO, 1984 apud ABREU, 1994, p. 108). Todavia, o significado estruturante do engenhoso fidalgo tem sido, em grande medida, soterrado pela crítica e historiografia literária, que ainda resistem em aceitar ou perceber que o precursor mais próximo dos heróis portugueses está nas aventuras ontológicas de Dom Quixote e não no individualismo econômico e filosófico que Robinson Crusoé converte em realismo formal ou na tríade Stendhal/Balzac/Flaubert, consagrada sob a condição de realismo moderno. Essa linha de pesquisa, embora muito promissora, ainda carece de análises que façam um mapeamento mais detalhado da presença do herói cervatino no romance português em busca de seu significado composicional. Dentro do que foi possível apurar nos limites deste artigo, fica a certeza de que a escrita romancística lusitana perfaz um percurso genealógico em que os cavaleiros andantes, ao lado dos pícaros, assumem dimensões basilares, sob variadas penas e aspectos. 


\section{REFERÊNCIAS}

ABREU, Maria Fernanda de. Cervantes no romantismo português: cavaleiros andantes, manuscritos encontrados e gargalhadas moralíssimas. Lisboa: Editorial Estampa, 1994.

BAKHTIN, Mikhail. Questóes de Literatura e de Estética: a teoria da literatura. São Paulo: Hucitec, 2010.

BRUNO, Sampaio. A geração nova. Porto: Lello \& Irmão-Editores, 1984.

CANDIDO, Antonio. O discurso e a cidade. 3. ed. São Paulo; Rio de Janeiro: Duas Cidades; Ouro sobre Azul, 2004.

CASTELO BRANCO, Camilo. A Brasileira de Prazins. Rio de Janeiro: Nova Fronteira, 1995. . A Mulher Fatal. Lisboa: Parceria A. M. Pereira, 1968. . A Queda dum Anjo. Porto: Edições Caixotim, 2001. . A Sereia. Porto: Edições Caixotim, 2005. . Coração, Cabeça e Estômago. São Paulo: Martins Fontes, 2003. . Obras Completas. Porto: Lello \& Irmão, 1982-1994. 18 vol. . Onde Está a Felicidade?. Lisboa: Livros Horizontes, 1981.

CERVANTES, Saavedra Miguel de. Dom Quixote de La Mancha. Tradução de Viscondes de Castilho e Azevedo. São Paulo: Abril Cultural, 1978.

GARRETT, Almeida. Viagens na Minha Terra. São Paulo: Editora Três, 1973.

HERCULANO, Alexandre. Lendas e Narrativas. 2 Vol. Amadora: Livraria Bertrand, 1980.

$\neg$ ᄀ_. Novelas de Cavalaria Portuguesa. In: Opúsculos. Vol. IX. 3. ed. Lisboa: Antiga Casa Bertrand-José Bastos; Ca.-Livraria Editores, 1908.

KUNDERA, Milan. A arte do romance. Tradução de Tereza Bulhões Carvalho da Fonseca. São Paulo: Companhia das Letras, 2009.

LUKÁCS, Georg. A Teoria do Romance. São Paulo: Duas Cidades; Editora 34, 2000. . O romance histórico. Tradução de Rubens Enderle. São Paulo: Boitempo, 2011.

RAMA, Ángel. Des problemas para o romancista latino-americano. In: AGUIAR, Flávio; VANCONCELOS, Sandra Guardini Teixeira. (Orgs.). Ángel Rama: Literatura e Cultura na América Latina. São Paulo: Edusp, 2001. p. 41-110.

SCHWARZ, Roberto. Ao vencedor as batatas. 5. ed. São Paulo: Duas Cidades; Ed. 34, 2000.

SILVA, Luís Augusto Rabelo. Apreciações Literárias. In: Obras Completas. Vol. I. Lisboa: Empresa da História de Portugal, 1909.

SITI, Walter. O romance sob acusação. In: MORETTI, Franco (Org.). A cultura do romance. Vol. I. Tradução de Denise Bottman. São Paulo: Cosac Naify, 2009, p.165-195.

SOUSA, Moizeis Sobreira de. As fontes setecentistas do romance português. 278 p. Tese (Doutorado) - Faculdade de Filosofia, Letras e Ciências Humanas, Universidade de São Paulo. São Paulo, 2014.

Submetido em: 04/08/2014

Aceito em: 07/08/2014

Revista Letras, Curitiba, N. 91 p. 57-74, JAN./JUN. 2015.

ISSN 2236-0999 (VERSÃo ELETRÔNICA) 